\title{
The Dialectic of Dialectical Materialism and Discourse: A Scrutiny of Aravind Adiga's The White Tiger
}

\author{
Wajid Hussain $^{1} \&$ Khurram Shahzad Azam ${ }^{2}$ \\ ${ }^{1}$ National University of Modern Languages (NUML), Islamabad, Pakistan \\ ${ }^{2}$ Fatima Jinnah Women University, Rawalpindi, Pakistan \\ Correspondence: Wajid Hussain, Faculty Social Sciences, Shaheed Zulfikar Ali Bhutto Institute of Science and \\ Technology (SZABIST), Islamabad, Pakistan. E-mail: hussain@szabist-isb.edu.pk \& wajid.murree@gmail.com
}

\author{
Received: January 17, 2019 Accepted: February 8, 2019 Online Published: March 2, 2019 \\ doi:10.5539/ijel.v9n2p394 URL: https://doi.org/10.5539/ijel.v9n2p394
}

\begin{abstract}
The powerful social class exercises its hegemonic practices mainly on the basis of cognitive and discursive strategies. These strategies are accomplished through the exploitation of social knowledge, identities and ideologies, which, for their constitution, owe to the cognitive and discursive tactics themselves. The hegemony of the powerful social groups may, however, be countered when the manipulated individuals come to achieve enough knowledge and realization which protect their cognition from being manipulated further. Moreover, this achieved knowledge and realization also enables them to adapt themselves to the cognitive and discursive practices of the dominant class for the improvement of their socioeconomic position. The paper scrutinizes this notion in Aravind Adiga's The White Tiger. The study applies Marx's Dialectical Materialism and van Dijk's concept of Discourse and Manipulation. Additionally, the latter perspective also works as a model for the research. The study elucidates that the poor-rich divide, which is prevalent in the Indian society, is mainly created by the dominant class through their manipulation of the cognition of the dominated class. It also highlights the productive attempt by a lowest of the low caste individual to become a successful entrepreneur by adapting to and using the same cognitive and discursive tactics as employed against people like him by the powerful social class.
\end{abstract}

Keywords: dialectic, materialism, discourse, cognition, manipulation, caste

\section{Introduction}

The debate on the precedence of consciousness and social existence over each other continues to intrigue minds. Marxists argue for the priority of social existence and consider consciousness or idea not only as being secondary but a product of the material existence itself. Their concept of social classes is based on the same argument, which further explains that it is the human needs, in the social context, which generate idea for their support. This implies that in the Marxian view 'idea' or 'consciousness'- both of which indicate the same reality contextually - is not only secondary but depends for its existence on matter itself. That is why the socioeconomic differences, as Marxists hold, divide people much more strongly than the other differences, such as religion, ethnicity, race and gender, do.

In the Marxist approach, ideas which arise out of human needs are imposed in terms of ideologies which generate even fundamental beliefs and knowledge. They are communicated to and imposed on people through means of discourse, which is, according to poststructuralist view, a tool invented and used by human organism. Moreover, since social structures require their implementation and representation cognitively, these cognitive representations also determine the cognitive processes which are involved in the production and interpretation of discourse (van Dijk, 2014, p. 11). Similarly, this rule applies to the reverse relationship as well. This means that discourse also affects social structure and this happens through the cognitive representations of language users when they perform as social actors.

In this context, idea and language, both being the products of human needs, complement each other when social interaction takes place. When idea is communicated, it is expressed through or by language in terms of its suitability under a particular situation. Through the power as inherent in language, idea, for example, may be expressed direct or indirect, made explicit or implicit, generalized or specified, or presented as positive or 
negative. These linguistic strategies, which are manipulative either way, positively or negatively, exploit social ideologies and identities, which are themselves deemed as biased since these are also constituted or, at least, exploited for the vested interests. Among such socially constructed identities, caste is one, which significantly determines the socioeconomic system of the Indian society. This social identity determines all the aspects of the lives of the individuals of the Indian society. The socioeconomic sphere is affected most.

\subsection{Research Objective}

This research paper illuminates the use or abuse of power via cognitive and discursive practices by the powerful social groups for their vested interests, as reflected in Aravind Adiga's The White Tiger. In addition, the paper investigates the function of the socially established identities which are cognitively manipulated as fundamental knowledge. Lastly, it reflects the way the individuals of the lower strata emerge by employing the same cognitive and discursive strategies as have been used against them by the powerful social group.

\subsection{Concept of Dialectical Materialism}

One of the premises of this research concerns the Marxian view of social dialectic. This view finds the matter as the essence of everything including the idea as well. For this philosophy of Dialectical Materialism, Marx is indebted to Hegel as he derives the principles of his theory from the latter's concept of dialectic (Popper, 1940, p. 404). These principles, namely the laws of opposition, negation, and transition, explain that things oppose and negate each other, and from this opposition and negation emerges a transition as well. These rules apply to both, material as well as abstract realities. Marx disagrees with Hegel in the latter's preference to the abstract reality over the material world, which asserts consciousness determines life (Russell, 1946, p. 750).

Hegel supports his belief in the immateriality and precedence of the idea with his own logic. He argues that the world has been designed in such a way that the existence of its societies is pre-planned. In this regard, he looks at history as a phenomenon which has self-creation, self-organization and self-development (Wisdom, 1940, p. 249). Therefore, history, he holds, is an organic entity which unfolds in accordance with a planned rational process. Contrarily, Marx deems history as entirely a material process in which human needs arise. According to him, these needs, which, unlike those of animals, are neither limited nor static and which are conditioned by the human social existence, are always in search of their expression, satisfaction, and dissatisfaction. According to Cuddon, it is in this connection that the Marxian dialectical laws particularly relate to the economic and political history (Cuddon, 2012, p. 197).

Collectively in a society, there is conflict of interests between the individuals who produce labour and those who do not. This conflict arises because the mutual appropriation is regulated through the means of exchange. Resultantly, the two classes come to exist. However, according to Jakubowski, this conflict does not arise directly from the relations of production (Jakubowski, 1976, p. 16). He emphasises on the cognitive factor which helps in constituting and exploits the ideologies related to production and labour. Moreover, according to him, these ideologies are purely created by men as these solely concern human desires, needs and interests.

\subsection{Dialectical Materialism and Poststructuralist Linguistic Perspective}

The Marxian view of social dialectic is aligned with the poststructuralist linguistic view which deems language as merely a tool used by the language user. According to Barker (2008), though we cannot see language as representing the ways that more or less correspond to the material world, it is a tool used by human organism (Barker, 2008, p. 748). Mills (2004) views discourse as linguistic communication which operates between speaker and hearer as an interpersonal activity that is determined by some social purpose (Mills, 2004, p. 3). Foucault reinforces the point by saying that every society has its own "regime of truth: that is the type of discourses it harbours and causes to function as true" (as cited in Morris \& Patton, 1979, p. 46).

\subsection{Critical Discourse Analysis}

This point is strengthened and further elaborated by Critical Discourse analysts who associate the element of power with language. Fairclough (1995), for example, refers to three important features of Critical Discourse Analysis. These features encompass the dialectical relationship between ideology, language and power, the interaction occurring between discourse and the fundamental place of a text in relation to social research. He says that in the contemporary society, texts are progressively multi-semiotic. He adds that the texts the primary semiotic form of which is language increasingly combine language with other semiotic forms (Fairclough, 1995, p. 3).

Locke (2004) also finds discourse as always dependent on social context. To him, it is a "way of constructing the process of meaning-making in society" (Locke, 2004, p. 6). Van Dijk (2006) lays stress on the cognitive element in relation to this process of meaning making in society. According to him, the processes through which 
discourse influences mind, which itself involves highly complex process, are very intricate and "can only be managed in real time by applying efficient strategies" (Van Dijk, 2006, p. 365). He adds that discourse is made to create social manipulation and domination by the powerful social groups. He focuses more on what he himself terms as the discourse-cognition-society triangle, though he does not ignore the aspects of grammar, semantic, semiotic, pragmatics, rhetoric, stylistics, and other linguistic features such as verbal and paraverbal and multimodal instances of communicative events. According to him (as cited in Meyer \& Wodak, 2009, p. 66), a context is a cognitive representation, which is subjective, and a dynamic online model of the participants "about the for-them-now relative properties of the communicative situation". He terms this representation as a context model. He says that it is this mental model which defines the situation that controls the process of the required adaptation of discourse production and its comprehension to the social environment.

Based on these mental models there exist personal knowledge and belief of events and also the socially shared knowledge and beliefs of groups. The latter may, and or, in certain cases, based on the former through a generalization process. According to van Dijk, models typically represent both, the (instantiated, applied) knowledge and other social beliefs as well as the mental representations that define individual persons' self-awareness (cited by van Dijk, 1997, p. 190).

In addition, mental models not only share knowledge but also impose it (van Dijk, 1997, p. 189). This is because under the apparent observation of a language user, there are social knowledge and beliefs which determine his discourse. Van Dijk (1997) considers models much richer in producing and comprehending information than the discourses which are based on them (van Dijk, 1997, p. 198). For example, a journalist's story would not include every detail of the event. The journalist would take in only those events which he believes are relevant. Choices are regulated accordingly by the context model. Besides, there are other context-sensitive strategies also, for example degree of completeness, relevance and irrelevance, specification and generalisation, the manner of self and other presentation through us and them etc, as van Dijk (1997) says, "Self- and other-representation in context models, and the display of such identities and allegiances in talk, usually also show in the choice of pronouns" (van Dijk, 1997, p. 217). Citing Chmosky, he (2006) adds that while manipulation may substantially influence the formation or change of unique personal mental models, manipulative discourse generally aims at controlling the shared social representations of groups of people because these social beliefs in turn control people's talks and actions in many situations and over a relatively long period (van Dijk, 2006, p. 365). Once people's attitudes get influenced, further attempts for manipulation are scarcely necessary in order to make them act according to their established attitudes.

However, for the implementation of ideologies, the general strategies for manipulative discourse are largely semantic. The preferred meanings can, for example, be: emphasized and de-emphasized: (de-)topicalized; and made explicit or implicit and clear or vague accordingly. Besides, lexical selection may be made accordingly and the rhetorical devices may also be used.

\section{Methodology}

The study is a qualitative content analysis. It applies the dialectical materialist theory and the concept of Discourse and Manipulation for its textual analysis of Adiga's The White Tiger. These two perspectives have been embedded for the textual analysis under the concept of theoretical triangulation. This method offers multiple views for the analysis of a research question (Patton, 2002, p. 453). Triangulation may result in inconsistencies; however, it does offer, as Patton recommends, an opportunity to dig out deeper interpretation of the data. The research applies Van Dijk's concept of Discourse and Manipulation as a model as well.

\section{Discussion}

\subsection{Caste as a Superstructure for Economic Reality}

In this study, caste, an ideology unique to the Indian society, functions as a superstructure for Marxian view of socioeconomic reality. It is this caste system on which the social stratification of the Indian society is primarily based. However, the Marxist writers view this caste ideology as baseless unless related to the socioeconomic reality. Ranadive (1991), an Indian Marxist and writer, for example, lays stress on the necessity of integrating both these phenomena, caste system and class system. He says that the fight against untouchability and other social evils and the struggle against economic exploitation are indivisibly interlinked (Ranadive, 1991, p. 5). Though this integration has evoked a significant criticism as well, yet this research, for its convenience, treats the caste system as a superstructure of the socioeconomic reality itself.

\subsection{Manipulation as a Social Reality}

The White Tiger presents the socioeconomic war as waged between two main social classes. Through Balram's 
letter to the Chinese prime minister, Adiga exposes the strategies of the socially powerful class, which it employs for its socioeconomic hegemony on the weaker masses. Balram enlightens his addressee about the plight of his being half-baked along with thousands of others in India. He tells him that because of being half-baked "we were never allowed to complete our schooling" (Adiga, 2008, p. 10). Adiga also seems to deny any identity other than the one based on economic factor. His protagonist, for example, considers only two castes contemporarily: "Men with Big Bellies, and Men with Small Bellies. And only two destinies: eat-or get eaten up" (p. 54).

This social inequality is created through manipulation, which is, according to van Dijk (2008), a practice by dominant groups for the reproduction of their power. According to him, dominant groups, for the achievement of their manipulation, persuade, provide information, educate, instruct and perform other social practices which aim at influencing the knowledge. A general strategy for manipulation is the exploitation of monopoly over scarce social resources. Contextually, the magazine Balram happens to find at a bookstall alongside the road while waiting for his master and mistress who are busy in shopping inside a mall, is an example of the utilization of such social resources by the powerful social class. This magazine, which is published regularly on weekly basis, is aimed for the psychological management of the poor classes. The cover page depicts an elite class lady "who is huddling with fear of a murderer who is mentally and sexually deranged that no one reader would want to be like him" (Adiga, 2008, pp. 125-126). The story always ends with the murderer caught by a police officer. All the stories, which have more or less the same plot, are meant to teach the servant class the lesson of unconditional servitude for the master class.

The novel mentions another social resource as utilized as a strategy by the Indian ruling class in order to project a biased picture of their country to the foreign guests like the Chinese Premier. It is in the same context that Balram has already warned the Chinese Premier to be careful about the "booklet full of information about India's past, present and future" he will be provided with by the Indian government officials. Along with this booklet, he tells him, he will receive "take-home sandalwood statues of Gandhi" as well.

Adiga also raises his concern about the exploitation of education system by the ruling classes as a source for their vested interests. For their hegemonic agenda, they manoeuvre school syllabi. Balram tells the Chinese Premier that the minds of the children of the lower class are manipulated through teaching them manipulated knowledge. He recalls some lines from his school days, which teach the caste-ridden individuals that they should be proud and thankful to God because they are living in "a glorious land". The lines further explain that this land is glorious because it is here that the Lord Buddha received his enlightenment and the River Ganga is also flowing (p. 34).

According to van Dijk (2008), people are manipulated as long as they lack knowledge and information required. The acquisition of enough knowledge saves them from being manipulated further. Balram, who as a lowest of the low caste individual has suffered from manipulation significantly, comes to have the knowledge enough to realize his exploitation at the hands of the dominant class. Moreover, he not only learns to counter these tactics but also uses them, especially when he writes letter as a means to communicate to the Chinese Premier. In addition, his intense reading and appreciation of Rumi, Iqbal and Ghalib, the great Muslim poets, who have been a constant source of inspiration for him, also betrays his practical wisdom while choosing effective literature. He feels greatly indebted to Iqbal whom he also quotes, "They remain slaves because they can't see what is beautiful in this world" (Adiga, 2008, p. 27). According to Van Dijk, literature may also function for manipulation, positive or negative, of the mind.

\subsection{Manipulation as a Cognitive Reality}

The process of manipulation starts from the exploitation of fundamental knowledge, beliefs, opinions and ideologies, which are cognitive phenomena and which control the actions of the individual concerned. In The White Tiger, Adiga shows that the caste system with all of its associated ideologies is a very effective tool for the dominant groups in the Indian society to manipulate the minds of the weaker masses. These dominant groups always keep the poor majority haunted by the issue of their identity. Adiga seems to convey that a low caste individual has no identity of his own. In this context, Balram shares with the Chinese premier the story of his identity. He tells him that for his identity he was at the mercy of the superior class which connected him with the sidekick of the god Krishna. He adds that after naming him Balram, which means the sidekick of the god Krishna, his teacher asked him if he knew what his (the teacher's) name was. When Balram replied in negative, the teacher laughed and said "Krishna" (pp. 13-14).

About the gods which supposedly determine the identity of the lower caste individuals like him, Balram tells his addressee, "These are the kinds of gods they have foisted on us, Mr. Jiabao" (p. 19). This identity, which his society has given him, keeps haunting him in days to come. For example, when he visits the taxi driver to learn 
driving, the latter discourages him from pursuing the profession of driving, reasoning that "only a boy from the warrior castes can manage that" (p. 56). The driver tells Balram that because of his inferior caste he does not have enough aggression in his blood and that only Muslims, Rajputs and Sikhs can become drivers because they are warrior-like people. The driver adds that sweet-makers cannot last long in fourth gear (p. 56). The driver's words disappoint Balram immensely and he regrets being a Halwai, “Ah, they're Halwais, making sweets and tea is in their blood" (p. 63).

The novel shows a ubiquitous representation of multiple gods in the Indian society and suggests that these gods are merely meant for the manoeuvring of the social cognition. The protagonist informs the Chinese prime minister that once he came across a big poster of Sonia Gandhi who was holding a hand up as if waving to him and that he also waved her back (Adiga, 2008, p. 135). He continues that he yawned, closed his eyes and slipped down his seat. He says that the next moment he happened to look at the splendid sticker of the goddess Kali "who is a very fierce black-skinned goddess" (p. 135). This magnetic sticker, which is a discursive strategy, presents the goddess Kali as a sign of reverence especially for the lower caste people, whereas the image of the politician Sonia Gandhi is also meant for the projection of the same ideology yet in a lighter way. Balram also discusses with him that he had seen a large bronze statue of Mahatma Gandhi with his typical walking stick. He adds that behind Gandhi a huge crowd of the Indian people appeared "being led from darkness to light" (p. 136). Adiga, through his protagonist, wants to convey that these images of gods and of prominent leaders like Gandhi are merely meant to restrict the freedom of the minds of the poor strata of the society and that for the ruling classes, these signs have no value at all. This implication becomes clearer when Balram narrates that a deal of mega corruption is settled by his masters near the statue of Gandhi. After this deal has been settled, one of his masters, who suddenly happens to look at Gandhi's image, sneers and shouts, "We're driving past Gandhi." Referring to their act of bribing a minister, he laughs "It's a fucking joke, isn't it." (p. 137).

Side by side, the novel also shows that when the reality dawns at the people like Balram, it can change their mode of thinking. Balram, whom Adiga shows as bold enough to break the social stereotypes even being an individual of the lowest of low class, is sharp enough to get at the tactics as employed by the dominant social class which has been manipulating the minds of the people like him. With this realization, Balram feels no hesitation to express his grudges against the values the rival class has imposed. He condemns all the gods which are, according to his calculation, as many as 36,000,004 and which, he says, offer "many choices" as well. He looks at the stickers of goddess Kali and "suck my tongue out at the old witch" (p. 156). Scornful, he says as to the arse of which god out of 36000004 he should kiss as an invocation to start his letter with.

This knowledge and realization of the reality also enables him to see and analyse the world beyond his own society as well. He has realised not only the plight of the lower classes of the Indian society he belongs to but the misery of the oppressed section generally of the whole world as well. He comes to know the supremacy of the few countries like America which have imperialized many weaker countries. He comes to realize the tactics behind the power as exercised by the powerful social class. He also gets awareness about the power of propaganda literature for the manipulation of people's minds. That is why he warns the Chinese Premier about this type of literature which is meant for the distortion of reality. Accordingly, he advises the Chinese prime minister not to receive any American book on entrepreneurship in Bangalore. He advises him to read about the Indian entrepreneurs because future is "The century, more specifically, of the yellow and the brown man (p. 6)". About the Americans he says "They're so yesterday. I am tomorrow (Adiga, 2008, p. 6)." He has a firm conviction, "Entrepreneurs are made from half-baked clay" (p. 11).

Balram has learned the art of manoeuvring the minds and he applies it on the ruling class. It is through his tricks that he convinces Ashok and his father for his job in their house. He is even himself amazed at his skilful manipulation of his masters who proved an easy victim to his tactics. He says that his performance of wails and kisses and tears was worth seeing and that any viewer would think that "I'd been born into a caste of performing actors!" (p. 60). All the while, he is expressing to himself his extreme fury over the elite class, which has established itself at the cost of the poor people like him.

To convince the masters of the house, Balram adds another trick. He tells the old master that when he used to work in a tea shop which had a big photo of Gandhi hanging on one of its walls, the latter once visited to have tea (p. 60). The card Balram has played is the image of Gandhi. He knows that this image as created in the mind of his master will strengthen his (Balram's) case further. He, then, leaves no stone unturned to flatter him. He tells the old master that the latter's father was the best of the landlords in the village. He adds that since the father lord is dead now, "who will protect us now?" (p. 61). Balram's tricks work well. He gets his job secured. Moreover, this occasion proves an important milestone in his journey of entrepreneurship. 
The credit of Balram's rise goes to his mental acuteness, which helps him to understand not only the psyche of the master class but also the perspective they view the world from. He himself acknowledges his extraordinary ability to learn. He also admits that most of his practical ideas are borrowed from his ex-employer or his brother or all other people for whom he drove. He says that he is not "an original thinker" but "an original listener" (p. 47). He shares that working at the tea shop in Laxmangarh, he used most of his time to "spy on every customer at every table, and overhear everything they said." He says that this is how he thought that he could keep his education going forward because "I've always been a big believer in education-especially my own" (p. 52).

\subsection{Manipulation as a Discursive Reality}

According to van Dijk (2008), the strategy for the implementation of ideologies is mainly semantic. In other words, ideologies aimed for manipulation are reflected through text and talk. These semantic tactics may be implemented by presenting parts of text, for example, as bold, emphasized or italic etc. The desired meanings may also be stressed by: highlighting and de-(highlighting); (de-)topicalizing by using specific speech acts and more or less precise or specific local meanings; manipulating overt versus covert information; lexicalizing, and employing metaphors and other rhetorical figures. Similarly, a talk may be more or less intonated or uttered speedily or slowly.

\subsubsection{Giving Many/Few Details; Being General/Specific, Vague/Precise, Explicit/Implicit Etc}

One of these strategies for manipulation is generalization through which concrete specific events are generalized into general knowledge, attitude and even into fundamental ideologies. The novel provides many examples of manipulation through this way. For example, the protagonist informs the Chinese prime minister that the Indian ruling class shows the foreign guests like him only the specific places like Delhi and Bangalore, which are the most advanced cities of the country, and forms, with this specific presentation, a general image of the whole country. He tells him that it is a part of this strategy that rickshaws are prohibited from entering the posh parts of Delhi "where foreigners might see them and gape" (Adiga, 2008, p. 27). He adds that the road outside these specific posh parts of Delhi is full of these "thin, sticklike men, leaning forward from the seat of a bicycle, as they pedal along a carriage" (Adiga, 2008, p. 27).

Adiga also shows how the ruling class forms general and fundamental ideologies with the help of some specific events. These ideologies are generally meant to be practiced by the poor masses. In this context, Balram recalls his school syllabus which had similar kinds of ideologies to be taught to the lower caste children. The lines teach the children of the lower castes that they are blessed because they are living in the glorious land of India which owns the Lord Buddha and the River Ganga (p. 34).

\subsubsection{Self Versus Other Presentation/Emphasizing Positive/Negative Meanings; Using Us and Them}

Positive 'self' and negative 'other' presentation is also a typical strategy for the implementation of ideologies. This strategy also largely depends on semantic forms for its application. This semantic projection of positive self and negative others has a variety of means to be utilized. A strong polarization may, for example, be employed through the use of $U s$ and Them. These personal pronouns are very effective to create a strong emotional impact in people's mental models. Adiga makes a significant use of the polarization of these personal pronouns in order to show the polarity existing between the social classes. Balram seems obsessed with this schism and expresses it frequently. On one occasion, while providing the Chinese premier with the detail about Delhi, the capital city of India, he sarcastically mentions the following typical words associated with this city: "capital of our glorious nation", "the seat of parliament", the seat of the president and ministers", "the showcase of the republic". He, then, adds that this is how "they call it" (p. 118). The italicized they is an exophoric reference. However, the reader feels no difficulty to get at the idea it conveys. Earlier, the novel has mentioned italicized 'Ours' as well, when Balram has informed Mr. Jiabao that the body of a rich man is a premium cotton pillow which is "white and soft and blank. Ours are different" (p. 26).

Adiga frequently applies this technique in the novel in order to show a strong emotional detachment between the peoples of the opposite classes and a profound sense of belonging among the people of the same class. Balram recalls his master's (Ashok's) visit to the servant room where the former is staying with a colleague. His description of his master's attitude shows as if his master were an alien with a set of completely different feelings and habits. He says that the master sat down on a bed and started poking it with his fingertips and "I saw the room with his eyes; smelled it with his nose"... because "I had already begun to digest my master" (p. 79).

The pronoun his associated as an attribute with nouns, such as "eyes", "nose", and "fingers", shows a complete lack of understanding between the two social classes and their apathy for each other, though in this example and the two given before it, the strategy of the use of personal pronouns like Us and Them for the sake of positive 
'self' and negative 'others' presentation has been used on behalf of the suffering class.

Besides the use of pronouns for the sake of self and other presentation, the novel has also other semantic forms to offer. For example, Balram uses taboos such as arse, and, more importantly, he attributes these words to as sensitive entities as gods themselves in order to express his hatred against them because he thinks them as a tool used for the manipulation of the poor class. At the start of his letter to the Chinese premier, he thinks that he should also "start off by kissing some god's arse". He also asks sarcastically as to the arse of which god out of 360004 he should kiss.

In addition, the novel shows that between both the social classes phenomenal differences exist at phonetic and phonological levels as well. For example, Balram's master, Ashok, and his wife Pinky enjoy Balram's mispronunciation of the word, which are generally used in the discourse of the upper class, to the extent of humiliating him. Balram pronounced, for example, Pizza as Pijja, and "The two of them burst into giggles" (p. 154). Similarly, Balram entertains them through his mispronunciation of the word "mall" as well. He calls it "maal". This amuses his master and mistress to such an extent that they ask him to reiterate it for them. Adiga, through presenting these differences at phonetic and phonological level, seems to convey that this linguistic demarcation determines the class distinction as well.

However, despite feeling insulted because of his mispronunciation, Balram is also satisfied because he "knew it was a trap" which he uses to catch the consciousness of his master and mistress. He keeps entertaining them for the sake of his own interests, as he himself says, "Some good came out of my humiliation-I was glad for that, at last" (p. 147).

\section{Conclusion}

Adiga's novel, The White Tiger, highlights the socioeconomic power as exercised mainly via cognitive and discursive strategies. Through the persona of a low caste individual, Balram, it shows that the dominant social class manipulates the minds of the dominated class basically in order to make the latter act in the best interests of the former. This control over mind is achieved through a variety of tactics. First of all, social resources of discourse, such as media, newspapers, magazines, pamphlets etc. are hegemonized. Then through this literature the minds of the targeted people are controlled. Furthermore, within the use of literature itself there exist various tactics. Positive 'self' presentation and negative 'others' presentation is one of them. Such presentation itself is accomplished via various techniques. For example, the powerful classes use words with positive connotation for themselves and negative words for others. Secondly, they may specify and highlight those things which favour them for maintaining their monopoly. Similarly, facts against them may be highlighted or de-highlighted accordingly. The desired facts may be specified or generalized as the situation demands.

The study has also shown that these tactics as employed by the socially powerful work for them as long as the targeted individuals or groups have no awareness about them. But as soon as these tactics are exposed to them, they are not only disillusioned about these stereotypes but start using the same strategies for their own interests as well. The study has highlighted that Balram, who is the representative of the unprivileged social class, succeeds in escaping from the plight of being an individual of the lower caste and improving his social status by becoming a successful entrepreneur.

\section{References}

Adiga, A. (2008). The White Tiger. New Delhi: Harper Collins.

Barker, C. (2008). Cultural Studies: Theory and Practice. California: Sage Publications.

Cuddon, J. A. (2012). Dictionary of Literary Terms and Literary Theory (p. 197). John Wiley \& Sons.

Fairclough, N. (1995). Critical Discourse Analysis: The Critical Study of Language. New York: Longman.

Jakubowski, F. (1976). Ideology and superstructure in historical materialism. Allison \& Busby.

Locke, T. (2004). Critical Discourse Analysis. London, New York: Continuum International Publishing Group.

Meyer, M., \& Wodak, R. (2009). Methods of Critical Discourse Analysis. Introducing Qualitative Methods Series (p. 66). London: Sage.

Mills, S. (2004). Discourse. London: Routledge. https://doi.org/10.4324/9780203487136

Morris, M., \& Patton, P. (1979). Michel Foucault: Power, truth, strategy. Sydney: Feral Publications.

Patton, M. (2002). Qualitative Research and Evaluation Methods. Thousand Oaks, CA: Sage.

Popper, K. R. (1940). What is Dialectic? In G. F. Stout (Ed.), Mind: A Quarterly Review of Philosophy and 
Philosophy (Vol. 49, No. 196, pp. 403-426). Oxford University Press.

Ranadive, B. (1991). Caste, Class and Property Relations. Calcutta: National Book Agency.

Russell, B. (1946). History of Western Philosophy. London: Routledge.

van Dijk, T. A. (1997). Cognitive Context Models and Discourse. Language Structure, Discourse and the Access to Consciousness, 190. https://doi.org/10.1075/aicr.12.09dij

van Dijk, T. A. (2006). Discourse and Manipulation. Discourse \& Society, 17(2), 359-383. https://doi.org/10.1177/0957926506060250

van Dijk, T. A. (2008). Discourse and Power. London: Palgrave Macmillan. https://doi.org/10.1007/978-1-137-07299-3

van Dijk, T. A. (2014). Discourse-Cognition-Society: Current State and Prospects of the Socio-cognitive Approach to Discourse. In H. Christopher \& C. Piotr (Eds.), Contemporary Studies in Critical Discourse Analysis (pp. 121-146). London.

Wisdom, J. O. (1940). Hegel's Dialectic in Historical Philosophy. Philosophy, 15(59), 243-268. https://doi.org/10.1017/S0031819100036172

\section{Copyrights}

Copyright for this article is retained by the author(s), with first publication rights granted to the journal.

This is an open-access article distributed under the terms and conditions of the Creative Commons Attribution license (http://creativecommons.org/licenses/by/4.0/). 